\title{
Length-Weight and Some Morphometric Relationships of Valamugil seheli from Sudanese Red Sea Coast
}

\author{
Motasim Ali Mokhtar ${ }^{*}$, Osman Mohammed Farah², Sayed Mohammed Ali ${ }^{3}$ \\ ${ }^{1}$ Ministry of Animal Resources and Fisheries, Fisheries Research Centre, Red Sea Fisheries Research Station, \\ Port Sudan, Sudan \\ ${ }^{2}$ Faculty of Marine Sciences and Fisheries, Red Sea University, Port Sudan, Sudan \\ ${ }^{3}$ Faculty of Science, University of Al-Neelain, Khartoum, Sudan \\ Email: *motas122@yahoo.com
}

Received 22 October 2015; accepted 6 November 2015; published 11 November 2015

Copyright (C) 2015 by authors and OALib.

This work is licensed under the Creative Commons Attribution International License (CC BY).

http://creativecommons.org/licenses/by/4.0/

\section{(c) (i) Open Access}

\begin{abstract}
Length-weight relationship is an essential biological parameter needed to appreciate the suitability of the environment for any fish species. That is why many fishery biological studies give an importance to it. The relationships between total length and body depth and girth are very important in estimating the allowable catch and appropriate mesh size to be used in a fishery. Length-weight and some morphometric relationships (depth-total length, girth-total length and dorsal fin length and anal fin length-total length) of Valamugil seheli (local name Arabi) (Mugilidae) were calculated from the commercial catches landed at Port Sudan Fish Market from February 2010 to January 2011. The length-weight relationship was found to be stronger in females $(\mathrm{W}=$ $\left.0.0073 L^{3.1047}, R^{2}=0.966\right)$ than in males $\left(W=0.0074 L^{3.0954}, R^{2}=0.926\right)$. But for sexes combined it was $y=0.007 x^{3.114}, R^{2}=0.961$. Values of $R^{2}$ were high in all cases. The length-weight relationship indicated the cube law $\left(W=\mathrm{aL}^{3}\right)$ for males, females and the sexes combined relationships. The power equations for the relationship between total length and body depth, and total length and girth, for the two sexes have higher $\mathrm{R}^{2}$ than the strait line equations and hence better describe the two relationships. The two relations were stronger in females than in males. The relationships between total length and the first dorsal fin length and anal fin length of sexes combined of $V$. seheli were not as strong as the total length-total weight relationship.
\end{abstract}

\section{Keywords}

Body Depth, Body Girth, Length-Weight Relationship, Valamugil seheli

Subject Areas: Animal Behavior, Aquaculture, Fisheries \& Fish Science

\footnotetext{
${ }^{*}$ Corresponding author.
}

How to cite this paper: Mokhtar, M.A., Farah, O.M. and Ali, S.M. (2015) Length-Weight and Some Morphometric Relationships of Valamugil seheli from Sudanese Red Sea Coast. Open Access Library Journal, 2: e1621. 


\section{Introduction}

The relationship between the length and weight of a fish is used by fisheries researchers and managers for two main purposes (Le Cren, 1951) [1]. First, the relationship is used to predict the weight from the length of a fish. This is particularly useful for computing the biomass of a sample of fish from the length-frequency of that sample. Second, the parameter estimates of the relationship for a population of fish can be compared to average parameters for the region, parameter estimates from previous years, or parameter estimates among groups of fish to identify the relative condition or robustness of the population. By convention, this second purpose is usually generically referred to as describing the condition of the species.

According to the Marine Fisheries Administration records in Sudan, Valamugil seheli constitutes high percent of the total fish landings and is available all the year round. It is the best local marine fish for preparing "Fasseikh" (wet-salted fishes) because of its good taste and texture (Faragalla, 2009) [2].

In practice, the use of morphometric measurements (body length, body girth, head length, fins length, eye diameter and jaw length) and meristics (fin ray, scale, teeth, gill raker and lateral line pore counts) to identify and classify fish is common. Morphometric measurements are generally presented as a proportion of total, standard and fork length, body weight and condition factor (Naeem et al., 2010 [3], and 2011a [4], b [5]). The aims of this study were to determine:

1) length-weight relationship of Valamugil seheli;

2) body depth-total length relationship of Valamugil seheli;

3) body girth-total length relationship of Valamugil seheli;

4) dorsal and anal fins-total length relationship of Valamugil seheli.

\section{Materials and Methods}

Random samples of about 30 fish of Valamugil seheli were collected monthly from the commercial catches landed at Port Sudan Fish Market from February 2010 to January 2011. Total length was measured to the nearest $\mathrm{mm}$ and total weight to the nearest $0.1 \mathrm{gm}$, then the data was entered to Excel package and the curve of the relationship between them was plotted. Values of the constants (a) and (b) were obtained from the relationship according to Abd El Razik (1987) [6] and Gulland (1985) [7] using the equation:

$\mathrm{W}=\mathrm{aLb}$

where:

$\mathrm{W}=$ total weight in grams;

$\mathrm{L}=$ total length in $\mathrm{cm}$;

$\mathrm{b}=\mathrm{a}$ constant of the relationship represents the slope of the equation;

$\mathrm{a}=\mathrm{a}$ constant of the relationship represents the intersect part of the " $y$ " axis.

Total length, body depth, body girth, dorsal fin length and anal fin length of Valamugil seheli were measured to the nearest $\mathrm{mm}$ then the data was entered to Excel package and the curve of the relationships between each one the four later parameters and total length were plotted. Values of the constants (a) and (b) for each relationship separately were obtained using power and linear equations as follow:

$\mathrm{B}=\mathrm{aL}{ }^{\mathrm{b}}$ (power equation)

$\mathrm{B}=\mathrm{aL}+\mathrm{b}$ (linear equation)

where:

$\mathrm{B}=$ one of these parameters body depth, body girth, dorsal fin length or anal fin length in cm;

$\mathrm{L}=$ total length in $\mathrm{cm}$.

\section{Results}

\subsection{Length-Weight Relationship}

The length-weight relationship was very strong, but there was a little difference between males and females (for males $\mathrm{R}^{2}=0.926$ and for females $\mathrm{R}^{2}=0.966$ ) (Figure 1 ). The sexes combined relationship is also very strong $\left(\mathrm{R}^{2}=0.958\right)$.

\subsection{Body Depth and Body Girth}

The relationship between total length and body depth, and total length and girth, for the two sexes are shown in 
Table 1 and Table 2 and Figures 2(a)-(d). The two relations were stronger in females than in males. The power equations shown in Table 1 and Table 2 have a little bit higher $\mathrm{R}^{2}$ value than the strait line equations and hence better describe the two relationships.

\subsection{Dorsal and Anal Fins}

The relationship between total length and the first dorsal fin length and anal fin length, are shown in Table 3 and Figures 3(a)-(d). These relations were not strong as total length vs. total weight relationship and were done for the sexes combined. For the relationship between total length and the first dorsal fin length the strait line equation have a little bit higher $\mathrm{R}^{2}$ value $\left(\mathrm{R}^{2}=0.6045\right)$ than the power equation $\left(\mathrm{R}^{2}=0.584\right)$ and are therefore more appropriate. The opposite is true for the relationship between total length and anal fin length where the power equation is a little bit stronger $\left(R^{2}=0.653\right)$ than the linear equation $\left(R^{2}=0.6382\right)$.

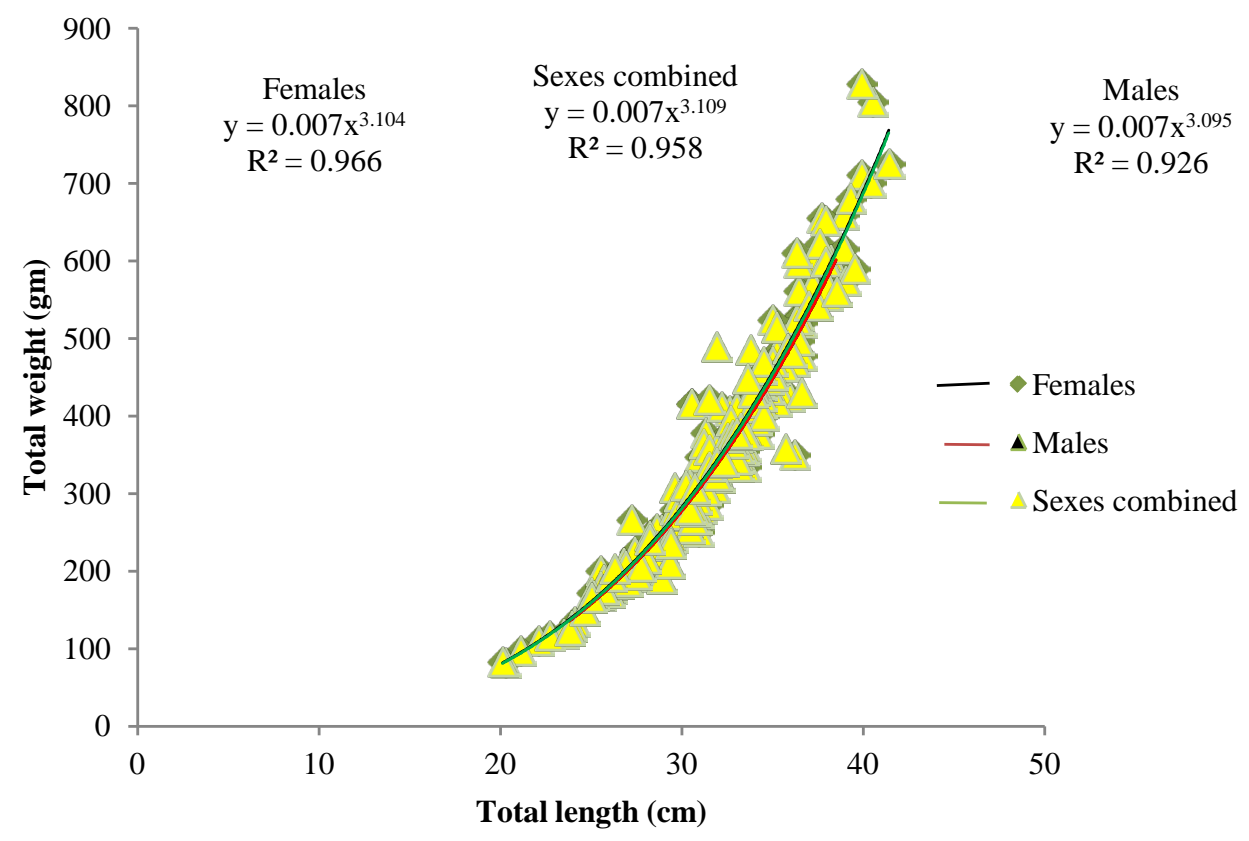

Figure 1. Length-weight relationship for males, females and sexes combined of Valamugil seheli.

Table 1. The relationship between total length and body depth of Valamugil seheli.

\begin{tabular}{ccccc}
\hline Relationships & Sex & Equation & Equations & $\mathbf{R}^{2}$ \\
& Male & Power & $\mathrm{y}=0.174 \mathrm{x}^{1.032}$ & 0.779 \\
Total length vs. body depth & & Straight line & $\mathrm{y}=0.204 \mathrm{x}-0.282$ & 0.764 \\
& Female & Power & $\mathrm{y}=0.204 \mathrm{x}^{0.997}$ & 0.837 \\
& & Straight line & $\mathrm{y}=0.204 \mathrm{x}-0.046$ & 0.824 \\
\hline
\end{tabular}

Table 2. The relationships between total length and body girth of Valamugil seheli.

\begin{tabular}{|c|c|c|c|c|}
\hline Relationships & Sex & Equation & Equations & $\mathbf{R}^{2}$ \\
\hline \multirow{4}{*}{ Total length vs. body girth } & \multirow{2}{*}{ Male } & Power & $y=0.642 x^{0.933}$ & 0.811 \\
\hline & & Straight line & $y=0.485 x+0.813$ & 0.795 \\
\hline & \multirow{2}{*}{ Female } & Power & $\mathrm{y}=0.537 \mathrm{x}^{0.992}$ & 0.889 \\
\hline & & Straight line & $y=0.522 x+0.044$ & 0.876 \\
\hline
\end{tabular}




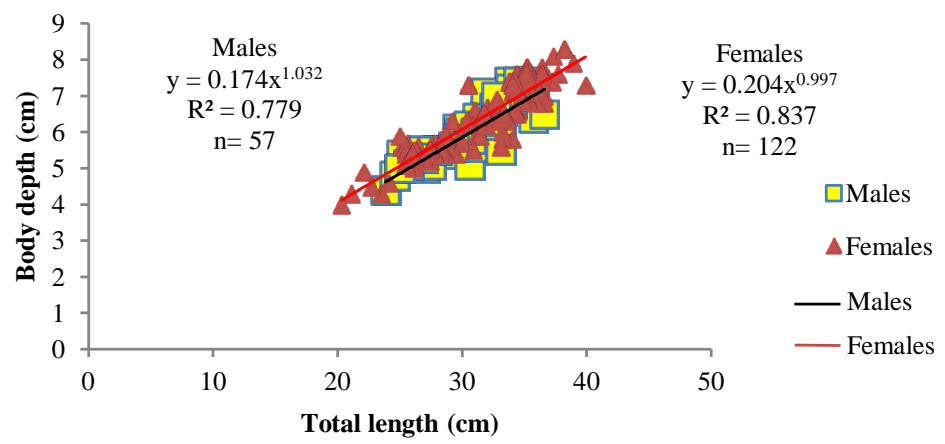

(a)

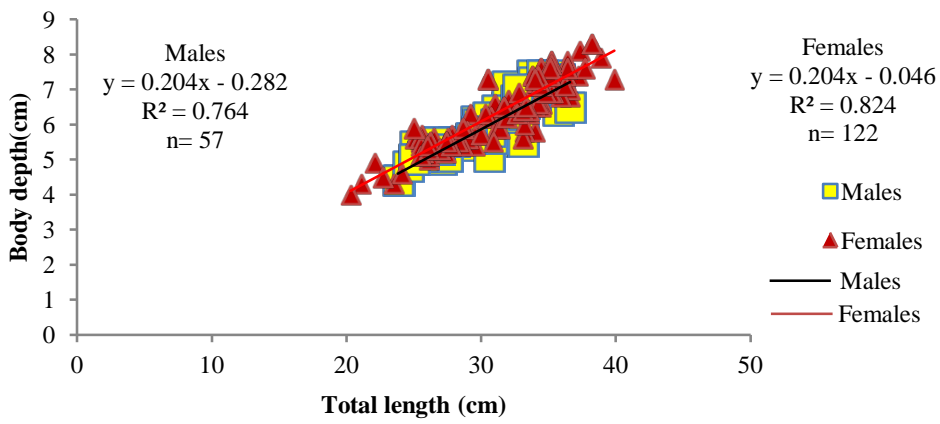

(b)

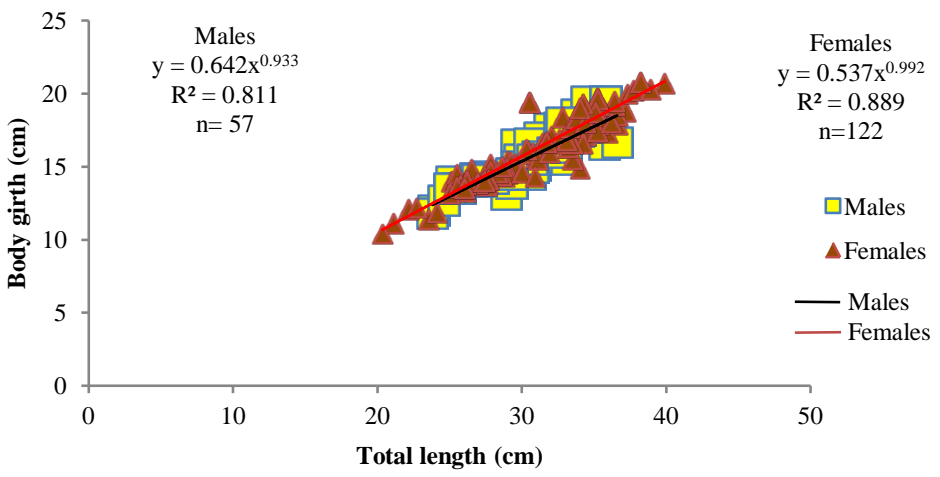

(c)

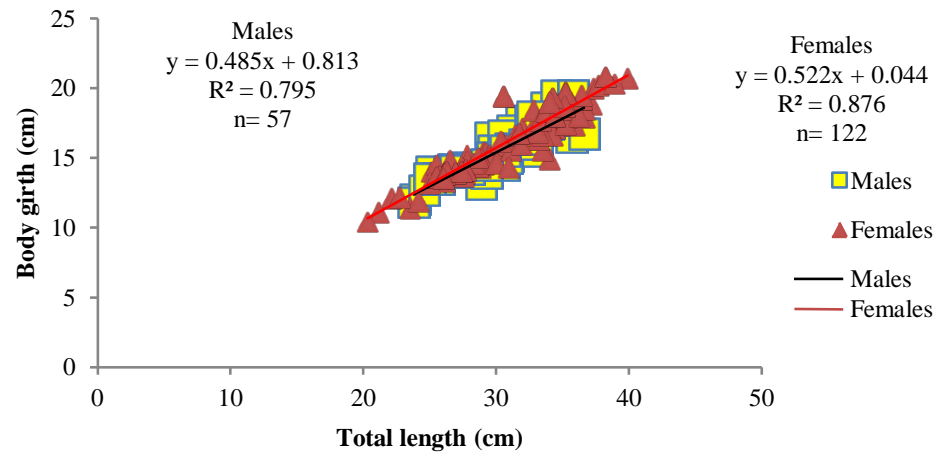

(d)

Figure 2. (a) Power relationship between total length and body depth of males and females of Valamugil seheli; (b) Straight line relationship between total length and body depth of males and females of Valamugil seheli; (c) Power relationship between total length and body girth of males and females of Valamugil seheli; (d) Straight line relationship between total length and body girth of males and females of Valamugil seheli. 
Table 3. Relationships between total length and first dorsal and anal fins of Valamugil seheli.

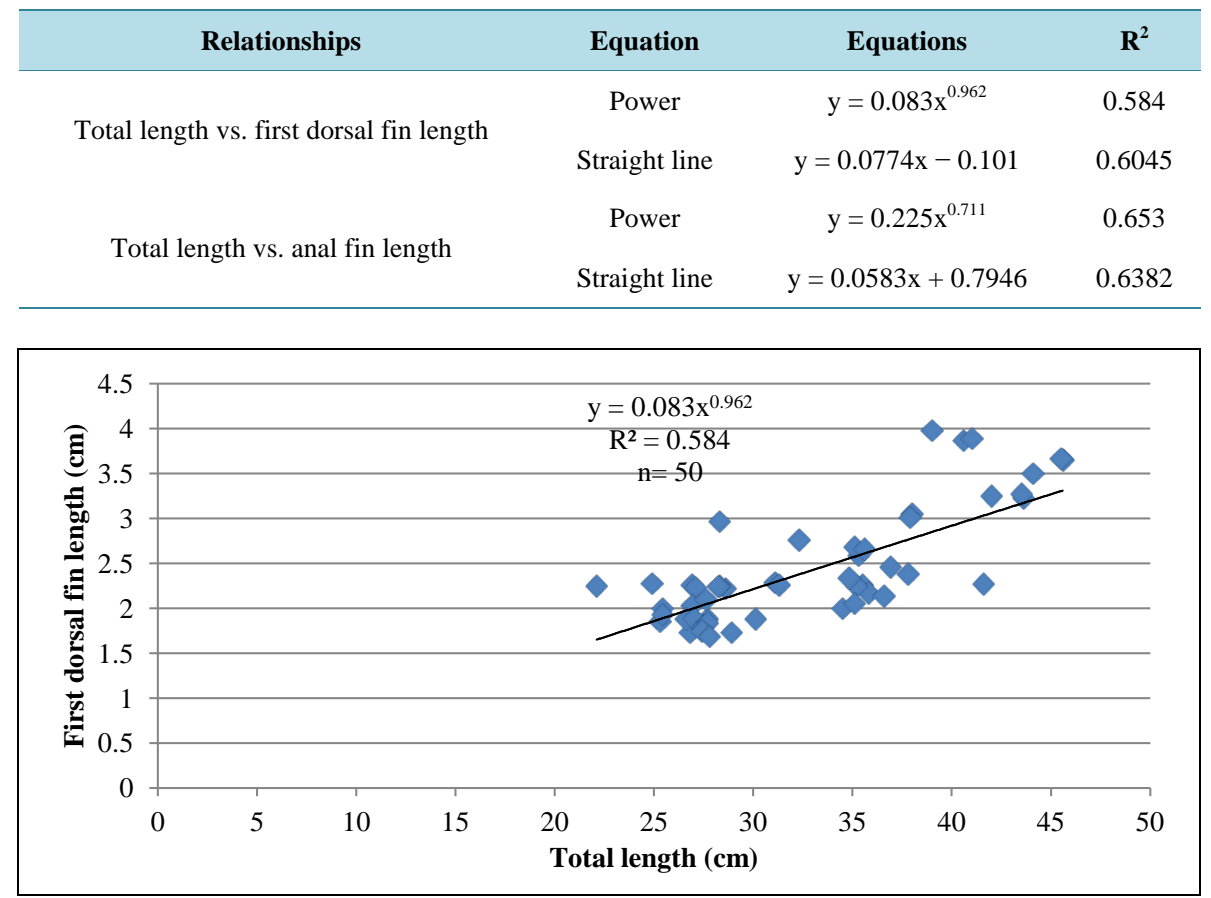

(a)

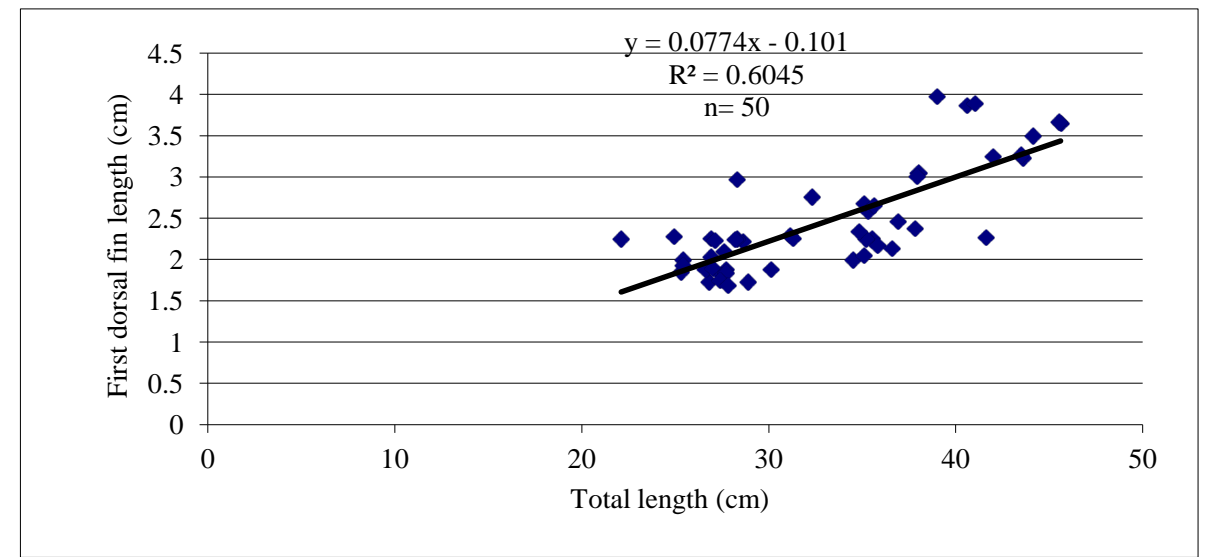

(b)

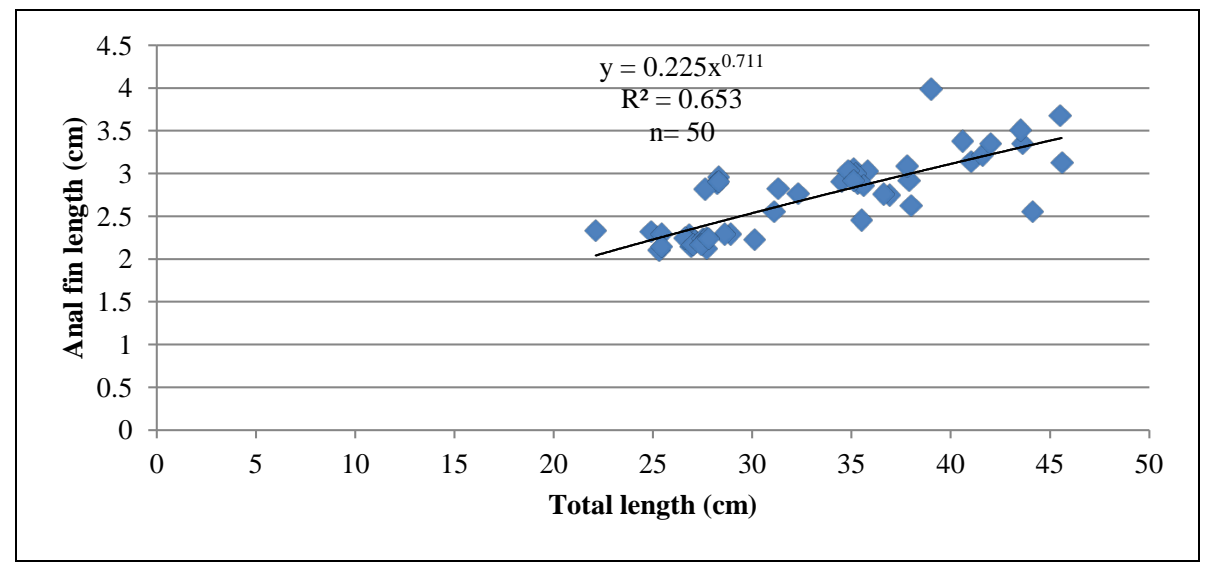

(c) 


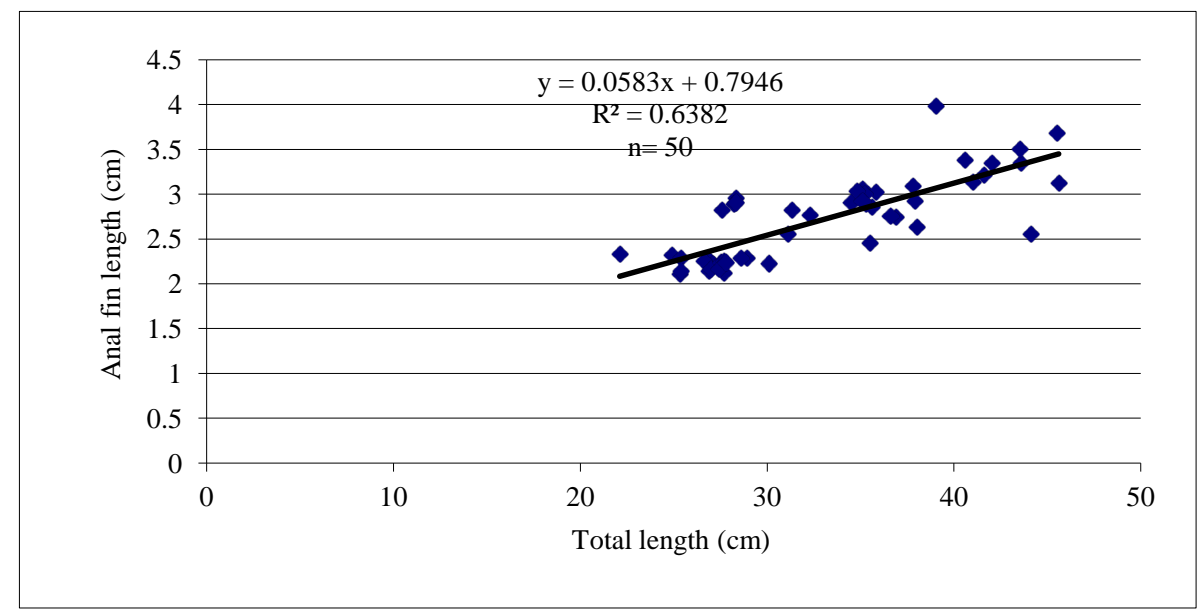

(d)

Figure 3. (a) Power relationship between total length and first dorsal fin length of sex combined of Valamugil seheli; (b) Strait line relationship between total length and first dorsal fin length of sex combined of Valamugil seheli; (c) Power relationship between total length and anal fin length of sex combined of Valamugil seheli; (d) Strait line relationship between total length and anal fin length of sex combined of Valamugil seheli.

\section{Discussion}

The length-weight relationship of Valamugil seheli was found to be a little bit stronger in females ( $\mathrm{W}=$ $\left.0.0073 \mathrm{~L}^{3.1047}, \mathrm{R}^{2}=0.966\right)$ than in males $\left(\mathrm{W}=0.0074 \mathrm{~L}^{3.0954}, \mathrm{R}^{2}=0.926\right)$, but there was no significant difference between sexes. Khalifa (2007) [8] estimated length-weight relationship for this fish from Abu Hashish area, Portsudan. He found that this relationship was significantly high in both sexes and the (b) value for females and males was 2.775 and 2.808 respectively. The variation of the (b) value between the two studies may due to the different times of the two studies. Moorthy et al. (2003) [9] estimated this relationship for $V$. seheli from Mangalore region-India to be $\mathrm{W}=0.0373 \mathrm{~L}^{2.6294}$ for males and $\mathrm{W}=0.0502 \mathrm{~L}^{2.5283}$ for females. Comparing with the present study the variations may be due to the different environmental conditions of the two localities. Borafy and Soliman (1988) [10] recorded positive allometric growth for V. seheli $(b=3.508$ in males and 3.462 in females) from UAE which is similar to results of the present study. This may be due to the similar environmental conditions in the two localities. Generally the present study indicated the cube law, $\mathrm{W}=\mathrm{aL}^{3}$ as proper representation of the length-weight relationship for V. seheli inhabiting Sudanese Red Sea coast. Renjini and Bijoy (2009) [11] estimated length-weight relationship of Liza parsia from Cochin estuary in India. The (b) value was 3.1938 for males and 3.0094 for females. Luther (1968) [12] estimated (b) values in Mugil cephalus. In both studies length and weight were positively correlated. This is similar to the case in the present study. A study by Rao et al. (2005) [13] regarding the length-weight relationship of Liza parsia in relation to industrial pollution gave (b) value of 2.4986 for males and 2.5210 for females. Moorthy et al. (2003) [9] reported the (b) value for V. seheli (unsexed) as 2.6207 showing a negative allomeric growth pattern.

The relationships of total length-body depth and total length-body girth for $V$. seheli were closely related for the two sexes. However, they were stronger in females $\left(\mathrm{R}^{2}=0.824\right.$ and 0.876 respectively) than in males $\left(\mathrm{R}^{2}=\right.$ 0.764 and 0.795 respectively). These parameters are very important in estimating the allowable catch and appropriate mesh size to be used. The values of body depth and body girth of this fish increase with increasing in total length. The average values of depth and girth for males and females of $V$. seheli were $5.93 \mathrm{~cm}, 6.31 \mathrm{~cm}$, $15.55 \mathrm{~cm}$ and $16.30 \mathrm{~cm}$ respectively. Khalifa (2007) [8] found these parameters for the same species from Abu Hashish area to equal $4.92 \mathrm{~cm}, 5.73 \mathrm{~cm}, 14.24 \mathrm{~cm}$ and $15.18 \mathrm{~cm}$ for males and females respectively. Bilal (2006) [14] found that the average values for males and females of Siganus revulatus were $5.83 \mathrm{~cm}, 6.2 \mathrm{~cm}, 12.53 \mathrm{~cm}$ and $13.27 \mathrm{~cm}$ respectively while for Siganus stellatus they were $9.19 \mathrm{~cm}, 9.08 \mathrm{~cm}, 19.25 \mathrm{~cm}$ and 19.2 respectively.

In the present study the relationships between total length and the first dorsal fin length and anal fin length of sexes combined of $V$. seheli $\left(R^{2}=0.60\right.$ and 0.63 respectively) were not as strong as the total length-total weight 
relationship ( $\mathrm{R}^{2}=0.926$ for males and 0.966 for females). This may be due to the differences of growth rhythm of the different parameters in each relationship. The relation between total length and anal fin length $\left(\mathrm{R}^{2}=\right.$ $0.6382)$ was stronger than the relation between total length and first dorsal fin length $\left(R^{2}=0.6045\right)$. Renjini and Bijoy (2009) [11] calculated $\mathrm{R}^{2}$ for the relationship between total length and anal fin length of the mullet Liza parsia from the Champakkara region of Cochin estuary, India, as 0.452 and for the relationship between total length and first dorsal fin length as 0.476 . They reported that these two relationships were positively correlated.

Both power and linear equations used in the present study to describe morphometric relationships of $V$. seheli have equal strength. The power equations however, had slightly higher $\mathrm{R}^{2}$.

\section{References}

[1] Le Cren, C.D. (1951) The Length-Weight Relationship and Seasonal Cycle in Gonad Weight and Condition in Perch, Perca fluviatilis. Journal of Animal Ecology, 20, 201-219. http://dx.doi.org/10.2307/1540

[2] Faragalla, A.M. (2009) Biochemical Studies of Three Marine Fishes, Fasseikh. Ph.D. Thesis, University of Khartoum, Khartoum, 104 p.

[3] Naeem, M., Salam, A., Gillani, Q. and Ishtiaq, A. (2010) Length-Weight Relationships of Notopterus notopterus and Introduced Oreochromis niloticus from the Indus River, Southern Punjab, Pakistan. Journal of Applied Ichthyology, 26, 620. http://dx.doi.org/10.1111/j.1439-0426.2010.01480.x

[4] Naeem, M., Salam, A., Ashraf, M., Khalid, M. and Ishtiaq, A. (2011) External Morphometric Study of Hatchery Reared Mahseer (Tor putitora) in Relation to Body Size and Condition Factor. African Journal of Biotechnology, 10, 7071-7077.

[5] Naeem, M., Salam, A. and Ishtiaq, A. (2011) Length-Weight Relationships of Wild and Farmed Tor putitora from Pakistan. Journal of Applied Ichthyology, 27, 1133-1134. http://dx.doi.org/10.1111/j.1439-0426.2010.01613.x

[6] Abd El Razik, H. (1987) Fish Biology. University of El Basra, Basrah.

[7] Gulland, J.A. (1985) Fish Stock Assessment: A Manual of Basic Methods, Marine Resources Service. Rome, Italy, 293.

[8] Khalifa, A. (2007) Some Environmental and Biological Aspects of Valamugil seheli and Valamugil buchanani from Abu Hashish Area, Portsudan. M.Sc. Thesis, University of Khartoum, Khartoum, 117 p.

[9] Moorthy, K.S.V., Reddy, H.R.V. and Annappaswamy, T.S. (2003) Age and Growth of Blue Spot Mullet, Valamugil seheli (Forskal) from Mangalore. Indian Journal of Fisheries, 50, 73-79.

[10] Borafy, F.A. and Soliman, F.M. (1988) Biology of Valamugil seheli Forskal from Inshore Waters of United Arab Emirates I. Age and Growth. Journal of the Marine Biological Association of India, 30, 164-170.

[11] Renjini, K.S. and Bijoy Nadan, S. (2009) Length-Weight Relationship, Condition Factor and Morphomtery of Gold Spot Mullet Liza parsia from Cochin Estuary. Indian Journal of Geo-Marine Sciences, 40, 567-571.

[12] Luther, G. (1968) Some Observation on the Biology of Liza macrolepis (Smith) and M. cephalus Linnaeus (Mugilidae) with Notes on the Fishery of Grey Mullets near Mandapam. Indian Journal of Fisheries, 10, 642-666.

[13] Rao, L.M., Bharatha Lakshmi, B. and Bangaramma, Y. (2005) Length-Weight Relationship and Condition Factor of Liza parsia in Relation to Industrial Pollution. Indian Journal of Fisheries, 52, 345-349.

[14] Bilal, S.A.S. (2006) Some Biological Aspects of Siganus rivulatus and Siganus stellatus from Abu Hashish Area in the Sudanese Red Sea Coast. M.Sc. Thesis, University of Khartoum, Khartoum. 